Теорія і практика

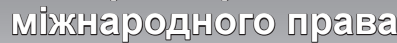

Ewa

\section{SAŁKIEWICZ- MUNNERLYN}

\section{The History of the Apostolic Nunciature in Poland and the Role of the Nuncio in Diplomacy}

\begin{abstract}
У статті представлено історію апостольської нунціатури в Польщі за весь період розвитку польсько-ватиканських відносин. Діяльність дипломатії Ватикану також пояснюється на основі дипломатичного права та принципів, таких як принцип пріоритету. Також представлено список усіх апостольських нунціїв у Польщі від початку дипломатичних відносин між Польщею та Ватиканом. Серед них було декілька майбутніх Пап.

Історія апостольської нунціатури в Польщі мало відома під час польсько-шведських воєн XVIII століття. На той час апостольська нунціатура в Польщі декілька років розташовувалася в Опаві (нині Чехія), на той час невеликому місті в імперії Габсбургів.

Ключові слова: повірений у справах, апостольська нунціатура, нунцій, дуайен дипломатичного корпусу, принцип пріоритету, Віденська конвенція про дипломатичні зносини 1961 року.

The article presents the history of the apostolic nunciature in Poland throughout history and Polish-Vatican relations. The activities of Vatican diplomacy are also explained, on the basis of diplomatic law and principles, such as the principle of precedence. A list of all apostolic nuncios in Poland from the beginning of diplomatic relations between Poland and the Vatican was also presented. Among them, there were few future Popes.

The history of the apostolic nunciature in Poland is little known during the Polish-Swedish wars in the 18th century. At that time, the Apostolic Nunciature in Poland was located in Opava, now (Czech Republic) for several years (at that time small city in the Habsburg Empire).

Keywords: Chargé d'affaires, apostolic nunciature, nuncio, dean of DC (diplomatic corps), precedence principle, the 1961 Vienna Convention of diplomatic relations.
\end{abstract}

The first apostolic nuncio to Poland was Luigi Lippomano, appointed by Juliusz III on January 13, 1555. (Kowalczyk 2004, Tygielski 1992). At that time, the nuncio's task was to implement the decisions of the Council of Trent in the various states in response to the devastation caused by the Reformation. Poland was one of the first ten European countries with which the Holy See established full, permanent diplomatic relations. It was one of the most important nunciatures, often marking the beginning of a great career for the diplomats headed there. The first Roman diplomat residing in Poland, and then elected pope, was the 13th Nuncio (from 1588 to 1589) Archbishop Ippolito Aldobrandini, later Pope Clement VIII (1592-1605). Archbishop Antonio Pignatelli, nuncio to Poland from 1660 to 1668, became pope in 1691 and took the name Innocent XII (he ruled the Church until 1700). In the 20th century, the first nuncio to our country, Archbishop Achille Ratti (1919-21), became pope in 1922 as Pius XI (he died in 1939). During the First Republic, 53 nuncios were accredited under the Polish kings, first in Kraków and then in Warsaw - the last was Archbishop Lorenzo Litta, who held office from 1794 to 1797. After the third partition of Poland, this nuncio tried for some time to carry out his office, trying to ensure the normal activities of the Church under the rule of Tsarist Russia.

УДК 341.01

https://doi.org/10.36952/uail.2021.3.31-37 (C) Ewa Sałkiewicz-Munnerlyn
Dr. Ewa SAŁKIEWICZ-MUNNERLYN chargé d'affaires at the Holy See in the years 15.08.1993-26.11.1993 and 17.01.1994-09.05.1994. 
A little-known history of the Apostolic Nunciature in Poland is the period of the Polish-Swedish Wars in the 18th century. In the wake of the progress of the Swedish troops in Polish lands and the withdrawal of Augustus II, the Apostolic Nuncio Orazio Filippo Spada was looking for a safe place and after many nods he settled in Opava in early 1705. This Silesian town on the territory of the Habsburg Empire belonged to the Diocese of Ołomuniec. It became quite coincidentally the capital of the Nuncio to the Polish king. (Kopiec 2002, 2009) Here until the end of his office lived Spada (1706), here he stayed throughout his nunciature Giulio Piazza (1706-1708 ), followed by Niccolo Spinola (1708-1709), who lived to see the victory achieved over Charles XII by Tsar Peter I at Poltava in July 1709. N. Spinola, in the wake of the retreating Swedish troops, he left Opawa in October 1709 and headed to Kraków to standed alongside Augustus II returning to the Polish throne.

\section{Relations between Poland and the Holy See in the 20th century}

Even before Poland regained its independence, the Holy See appointed the prelate Ambrogio Damiano Achille Ratti as apostolic visitator to The Republic of Poland and Lithuania on 25 1918. On June 6, 1919, the prelate Ratti was appointed the first apostolic nuncio to the Polish Government. Almost simultaneously, Benedict XV granted him the episcopal dignity, and he was consecrated on October 28, 1919, in the capital's Cathedral of St. John by the archbishop of Warsaw, Cardinal Aleksander Kakowski. The new nuncio was dismissed on 2 December 1920, but remained in office until 4 June 1921, when he left Warsaw. On February 6, 1922, he was elected pope and took the name Pius XI. For the rest of his life, he had a lot of sympathy for Poland. On February 10, 1925, he concluded the Concordat with Poland, a few months later by the bull Vixdum Poloniae unitas regulated the borders of Polish dioceses and ecclesiastical provinces, and on April 17, 1938, he canonized the Blessed Andrew Bobola SJ - priest and martyr. Archbishop Ratti was succeeded by Lorenzo Lauri (1921-1927), Francesco Marmaggi (1928-1936) and Filippo Cortesi (19361939). The latter left Poland with the diplomatic corps and government after the outbreak of World War II, but unlike other diplomats, he remained almost until the end of March 1940 in Romania, organizing aid for Polish refugees there. For the rest of his life (he died on February 1, 1947) he retained the title of Apostolic Nuncio to Poland.

After the end of World War II, the so-called Provisional Government of National Unity broke unilaterally on September 12, 1945 the Concordat of 1925. This situation, as well as the danger that the state authorities would prevent contacts between the Holy See and the Polish Episcopate, resulted, that Pius XII on 8 July 1945 granted special powers of attorney to the Primate Polish August Hlond and then Stefan Wyszyński.

It should be recalled the very interesting fact that although the Polish People's Republic and the Holy See had no diplomatic relations after World War II, the pre-war Ambassador of the Second Republic of Poland to the Holy See, Casimir Papée, was the dean of the Diplomatic Corps. From July 15, 1939 to 1958, he was the ambassador of the Republic of Poland to the Holy See. After the death of Pope Pius XII, he served as the Administrator of the Affairs of the Polish Embassy at the Holy See, and from 1972 until his death he was only an unofficial representative of the Polish Government in exile. The first official contacts between the Holy See and the then Government of the People's Republic of Poland were established in 1971, after a change of government team in Poland. The talks took place at the Vatican on 27-30 April of the same year, and delegations from both sides were chaired by: the Head of the Office for Religious Denominations, the vice-minister Aleksander Skarżyński and Archbishop Agostino Casaroli. Another series of talks and visits (among others heads of diplomacy of both sides) resulted in the establishment in July 1974 of a unique form of relations, the so-called Permanent Working Contacts Team between the People's Republic of Poland and the Holy See. The head of the Permanent Contacts Team from Poland (the first was Kazimierz Szablewski) was in Rome, but his Vatican counterpart, the Apostolic Nuncio to the Special Command of Archbishop Luigi Poggi, did not reside in Warsaw.

This state of affairs survived until the changes of 1989. The Holy See and the Polish People's Republic have restored diplomatic relations at the level of the Apostolic Nunciature and the Embassy respectively. The first heads of both institutions were Archbishop Józef Kowalczyk (he submitted authentication letters on December 6, 1989) and the then head of the Permanent Working Contacts Team Jerzy Kuberski (he submitted authentication letters on October 5, 1989). The second ambassador of Poland to the Holy See in the post-war period was appointed Prof. Henryk Kupiszewski, who submitted authentication letters on June 16, 1990. After his death (3 April 1994), Dr. Ewa Sałkiewicz (now Ewa Sałkiewicz-Munnerlyn, who is writing this article) was appointed the chargé d'affaires. Stefan Frankiewicz was subsequently appointed Ambassador of Poland to the Vatican, who submitted letters of authentication on July 11, 1995. In accordance with centuries-old international traditions and customs, the Apostolic Nuncioto Poland is, as in 50 other countries in the world, the dean of the diplomatic corps. Józef Kowalczyk was appointed the Apostolic Nuncio to Poland on August 26, 1989. Father Józef Kowalczyk, who received his episcopal consecration on 20 October 1989 in Rome from 
John Paul II. During his time as Apostolic Nuncio, the administrative structures of the Catholic Church in Poland were reorganized, the text of the Concordat between Poland and the Holy See was negotiated (signed on 28 July 1993 and ratified on 23 February 1998), with the help of the Polish Episcopal Conference and the faithful, the headquarters of the Apostolic Nunciature in Warsaw was renovated and expanded. The new part was opened and the chapel consacrated by Cardinal Angelo Sodano on April 30, 1998. (Wilk 2006)

\section{Seat of the Apostolic Nunciature.}

The building was purchased in September 1924 by the Polish Episcopate, then donated to the Holy See for the seat of the Nunciature. During the Warsaw Uprising, the building was destroyed and rebuilt on the basis of the project designed in 1947 by eng. arch. Władysław Tomaszewski. On February 14, 1949, having taken over the capital of Warsaw, Archbishop Stefan Wyszyński moved his residence to the rebuilt building of the Apostolic Nunciature, where also the Secretariat of the Primate of Poland was transferred. Primate Wyszyński resided in the seat of the Nunciature until December 27, 1952. In later years it housed the Religious Affairs Department at the Secretariat of the Primate of Poland. For some time the Nunciature also housed the offices of the Secretariat of the Polish Episcopate.

\section{Pontificia Accademia Ecclesiastica}

For 300 years, the Pontificia Accademia Ecclesiastica has been training personnel for the diplomacy of the Holy See and the Roman Curia (Garcia 2003). It is currently located in Palazzo Severoli in Piazza della Minerva, Rome. It was founded in 1701 by the priest Pietro Garagni as «Accademia dei Nobili Ecclesiastici» during the pontificate of Pope Clement XI. Over the centuries, graduates of the Academy have played an important role in the life of the Church. Her pupils were among others: five Popes: Clement XIII (Carlo Rezzonico, 1714), Leo XII (Annibale della Genga, 1783), Leon XIII (Gioacchino Pecci, 1832), Benedict XV (Giacomo della Chiesa, 1879) and Paul VI (Giovanni Battista Montini, 1921). From the beginning of the Academy's founding in 1701 to 2019, about 2,000 students graduated. For a long time in the Academy studied mainly clergy from Italy.

In the 20th century, the university opened its doors extensively to alumni from all over the world, including Poland. In 2001, for example, nine alumni studied there: beside the five Italians, an Australian, a Lithuanian, a Venezuelan and a resident of Burkina Faso. The Academy was also graduated by many Polish clergy, working in the diplomatic service of the Holy See.

\section{Relations between Poland and the Holy See}

* 1495 to Krakow arrives as a delegate of the Holy See bishop Girolamo Lando, which gives rise to the Polish nunciature.

* 1519 - the first Concordat between the Holy See and the Republic, approved by the sejm resolution and the bull of Pope Leo X. During the First Republic, two concordats were concluded in 1525 and 1737

* On January 13, 1555, Pope Julius III appointed bishop of Verona Aloysius Lippomano as nuncio to the Polish Kingdom. He reached Poland only in 1556 and was the first permanent nuncio to our country.

* On August 7, 1798, succumbing to pressure from Russia, the Apostolic Delegate Lorenzo Litta, with the power of attorney of the Holy See, established a new ecclesiastical province within Russia's borders - the Archdiocese of Mogilev. In an indirect way, it meant accepting the partition of Poland. * In 1919, the Apostolic Nunciature resumed operations in Warsaw. The first nuncio to independent Poland was the priest Achille Ratti - later Pope Pius XI. During the Battle of Warsaw in August 1920 he remained in Warsaw as one of two (alongside the Turkish representative) diplomatic representatives of foreign states. (Kelly: 443-446) Together with the Archbishop of Warsaw Zygmunt Kakowski visited soldiers in trenches, wounded in hospitals, maintained contact with bishops.

* On February 10, 1925, the Sejm agreed to ratify the Concordat with the Holy See.

* On September 4, 1939, nuncio Filippo Cortesi left Warsaw. The German occupation authorities liquidated the nunciature. The official link between the Holy See and individual bishops and religious orders in Poland was the Berlin Nuncio Cesar Orsenigo.

* On September 12, 1945, the Council of Ministers of the Provisional Government of National Unity passed a resolution to break the Concordat..

* On July 17, 1989, the Holy See and the People's Republic of Poland re-established diplomatic relations at the level of the Apostolic Nunciature and the Embassy. On August 26, 1989, John Paul II appointed the prelate Józef Kowalczyk, head of the Polish Section of the Secretariat of State, as apostolic nuncio to Poland, while raising him to the title of titular archbishop. Jerzy Kuberski became an extraordinary and $\mathrm{pl}$ ambassador to the Holy See.

* On July 28, 1993, the Concordat was signed by the government of Hanna Suchocka. Finally, the Sejm agreed to its ratification on 8 January 1998. 
List of existing bilateral agreements of the Republic of Poland - Holy See

\begin{tabular}{|c|l|l|l|l|l|}
\hline Lp. & \multicolumn{1}{|c|}{ Title of the contract } & \multicolumn{1}{|c|}{ Comments } & $\begin{array}{c}\text { Place of } \\
\text { signature }\end{array}$ & $\begin{array}{c}\text { Date of } \\
\text { signature }\end{array}$ & $\begin{array}{c}\text { Effective } \\
\text { date }\end{array}$ \\
\hline 1. & $\begin{array}{l}\text { Polish-Vatican Protocol on the } \\
\text { establishment of working contacts } \\
\text { between the Government of the Polish } \\
\text { People's Republic of Poland and the } \\
\text { Vatican City. }\end{array}$ & Rome & 06-07-1974 & 06-07-1974 \\
\hline 2. & $\begin{array}{l}\text { Concordat between the Holy See and The } \\
\text { Republic of Poland. }\end{array}$ & Warsaw & $28-07-1993$ & $25-04-1998$ \\
\hline $\begin{array}{l}\text { Agreement between the Polish } \\
\text { Government and the Polish Episcopal } \\
\text { Conference on the legal status of higher } \\
\text { education institutions established and } \\
\text { run by the Catholic Church, including } \\
\text { universities, separate faculties and higher } \\
\text { seminaries, and on the mode and scope } \\
\text { of state recognition of degrees and titles } \\
\text { awarded by these higher education } \\
\text { institutions. }\end{array}$ & $\begin{array}{l}\text { The Agreement of 30 June } \\
\text { of the People's Republic of } \\
\text { Poland and the Confederation } \\
\text { of The Episcopate Polish on } \\
\text { the regulation of the status } \\
\text { of papal universities and } \\
\text { the procedure and scope of } \\
\text { recognition by the State of the } \\
\text { degrees and academic titles } \\
\text { awarded by these universities } \\
\text { /MP No. 22, item 174/ }\end{array}$ & Warsaw & 01-07-1999 & 14-08-1999 \\
\hline
\end{tabular}

The tradition of the Pope sending his representatives to the local Churches dates back to the 4th century. The envoys represented the Pope at the general councils and local synods. Sometimes they were entrusted with dealing with various local issues. Over time, the practice of sending permanent le leaths to individual ecclesiastical provinces arose. The first such envoy was Ascholius, bishop of Thessaloniki, who represented Pope Damasi I at the court of the Eastern Empire. The situation of the papal envoys changed when in 756, as a result of the donation of the Franconian King Pepin the Little, the Church State was created from the lands taken from the Lombards. From that moment on, the legates went on a mission not only to the particular Churches, but also to the rulers.

Diplomatic relations between the Holy See and the states were revitalising in the 19th century. (Geremek 2004) This was influenced by the Vienna Congress (1815), which raised the importance and established basic diplomatic rules and adopted the most important procedures. Then among others, it was decided that the dean of the diplomatic corps, that is, the president of the representation of all diplomats accredited in the country, is the papal nuncio. This provision was taken over by the Vienna Convention on Diplomatic Relations of 1961.

At the same century, in 1809, Napoleon by decree «About the Papacy» abolished the Church State, which he annexed to France, and declared Rome a free city. The renewal of the Church State occurred as a result of a decision of the Congress of Vienna in 1815, but its but its very existence was threatened. The process of unification of Italian lands was just beginning, which challenged the continued existence of the papal domain. In 1870, the Italian army occupied Rome, which definitively ended the existence of the Church State. Although the Pope declared himself a «prisoner of the Italian authorities», paradoxically the importance of papal diplomacy at that time increased. It turned out that the loss of territorial power did not hinder, but facilitated the evangelizing mission of the head of the Catholic Church. It was then that the notion of the Holy See as a subject of international law, endowed with all the necessary attributes, yet lacking territory, took on particular significance. By this term, is meant the Bishop of Rome and the set of subsidiary bodies that make up the Roman Curia. These institutions serve the Pope in directing the universal Church and carrying out the Church's mission in the world. The growing importance of papal diplomacy has been reflected in the number of permanent diplomatic posts accredited to the Holy See, which increased from 17 in 1870 to 30 in 1929. Even Bismarck sought the help of papal diplomacy, calling on the Holy See to arbitrate in a dispute with Japan over the Marian archipelago in the Pacific. The great achievement of the Holy See's diplomacy was the final normalization of the situation of the papacy in Rome, which followed two years of secret negotiations with the government of Benito Mussolini.

The Lateran Pacts were signed on 11 February 1929, which included the Treaty, the Financial Convention and the Concordat. They stated among others, that Italy cedes the Vatican to the Pope and recognizes the sovereignty of the Holy See in international law. As Pope Pius XI rightly pointed out at the time, «this is a small territory, but we can say that it is the largest in the world.» The miniature Vatican City State created at that time is still the only form of the pope's modern power. 
During World War I, diplomats of the Holy See sought to win the favor of the crowned heads for the idea of breaking the war and concluding peace on terms acceptable to all. One of the elements of Pope Boniface XV's plan was the resurrection of the Polish state, although limited only to the territory of the Kingdom of Congress. The Papal envoys warned that if the war lasted longer, desperate masses would erupt. The prophesy came true. In 1918, there was a revolution that swept the Habsburg, Hohenzollern, Roman dynasties from the throne.

Pius XI wanted to help the Catholic in the Soviet Russia and accepted the idea of a secret mission of the Jesuit Micheld'Herbigny, whichwastolead tothecreation of asecrethierarchy of theCatholic ChurchinRussia. Fromthe very beginning, his mission was followed by soviet security, which placed its agent in the entourage of thePope's envoy. The whole project ended in defeat, secretly ordained bishops were imprisoned, some were murdered. Also in the Third Reich, the Nazis repressed many Catholics shortly after taking power. One day, Pope Pius XI, shocked and outraged by what was happening in the Third Reich, asked Eugenio Pacelli, nuncio to Berlin: «How can the Holy See still hold the Nuncio to Berlin? Does this reconcile with our good name?» He heard in response: «Holy Father, you can dismiss the nuncio from Berlin, but then what will we do? How will we be able to maintain contacts with The German Bishops?» This was the dilemma faced by the Holy See's diplomacy during the Second World War.

After the end of World War II, many accused Pius XII of being too gentle towards nazi Germany and fascist Italy for being silent in the face of the Holocaust drama. Leaked material from the Vatican's Secret Archive shows, that apostolic nuncios in all European countries where they could perform their mission, intervened in order to improve the fate of the population in the countries of occupied Europe and in defense of the Jews who were dying. Due to the conditions of the time, not every intervention could have been successful. Conference in Tehran and Yalta, did not bring peace, but the beginning of the Cold War. Stalin did not intend to abide by any obligations regarding the freedom of the Church. Ironically, he asked how many divisions the Pope had when one of the Western diplomats pointed out to him that the freedom of the Church should not be trampled upon. Nuncios were expelled from all so-called socialist countries, and all agreements linking the Holy See with the governments of eastern European countries were broken. Many clerics were arrested on suspicion of «espionage for the benefit of the Vatican.» In a demonstration trial in Sofia in 1952, bishop Eugeniusz Bossilkov was sentenced to death as a «Vatican spy» and the sentence was executed. Opportunities for diplomacy in the East emerged only during the pontificate of John XXIII and Paul VI.

Then the so-called Eastern Policy of the Holy See was launched, led mainly by its creator, Archbishop Agostino Casaroli. It was only the pontificate of John Paul II that led to fundamental changes in the Holy See's relations with eastern European countries, as well as the reconstruction of diplomatic relations after the fall of communism in 1989. In March 1990, the first ever papal nuncio, diplomat Archbishop Francesco Collasuono, arrived in Moscow.

\section{Papal Diplomacy}

Papal diplomacy is different from that of other countries. The representatives of the Holy See operate on two levels: in relations with the State and other actors of international law (ad extra mission) and internally, that is, in relation to particular Churches (ad intra mission). At the beginning of 2017, the Holy See maintained full diplomatic relations with 179 countries, and with thirteen had no diplomatic relations (Afghanistan, Saudi Arabia, Bhutan, Brunei, People's Republic of China, Comoros, North Korea, Laos, Maldives, Oman, Somalia, Tuvalu, Vietnam).

The diplomatic activity of the Holy See is governed by the motu proprio, issued on 29 June 1969 by Paul VI, entitled Sollicitudo omnium ecclesiarum. The Holy See's diplomacy is governed by international customs and conventions, in particular by the Vienna Convention on Diplomatic Relations of 18 April 1961. The Vatican City State is not a subject of international law, it has been the Holy See for centuries. As an independent subject of international law, it concludes international treaties and agreements, both bilateral with the country concerned and multilateral. A feature of bilateral agreements is their attitude towards regulating the legal situation of a particular particular Church. Multilateral agreements, on the other hand, are mostly not about the religious sphere. Today, the main objective of the Holy See's diplomacy is to protect the rights of the Church, religious freedom and the rights of believers, as well as respect for fundamental human rights and to promote peace and social order between peoples. Participation as an observer in the work of many international organisations is also an important direction for the Holy See. The unique position of the Holy See's diplomacy is not due to the fact that it is a political, economic or military force behind it. It is supported only by the moral authority of the Church and of the Pope.

Peace-keeping activities are among the most important tasks of the Holy See's diplomacy. Pope Pius XII, at the request of the Ambassador of Austria for a blessing for the soldiers on the front line, refused 
with the words: «I only bless peace.» During the pontificate of John Paul II, the diplomacy of the Holy See emphasized in particular the importance of free dom and respect for the rights of peoples to a sovereign existence. Numerous initiatives have also been taken to prevent the outbreak of armed conflict.

Sometimes such missions were successful, such as in 1987, when negotiations undertaken at the initiative of John Paul II prevented the outbreak of the Beagle Canal war between Argentina and Chile. The Holy See's contribution to ending the conflict in the Middle East is also significant. On other times, the missions of papal diplomacy have failed, such as for example before the start of the US-led coalition's attack on Iraq. However, thanks to the Vatican diplomacy, the conflict was not seen by the Arab world as a clash between the Christian world and the Islamic world.

The representatives of the Holy See are divided into:

Apostolic Nuncios - are papal legates, who act as permanent representatives of the Pope in the authority of the state and in relations with the ecclesiastical hierarchy of the place. They are entitled to the title of dean of the diplomatic corps by law. In 1992, the title pro-nuncio was also applied to those papal representativeswho perform the same duties as the nuncio but do not have the right of a deanery.

Apostolic Delegate - is the permanent representative of the Pope (usually with the episcopal sacrament) at the local Church in the designated territory or at the temporary diplomatic post of the Holy See (Apostolic Delegation). However, it does not have a diplomatic character.

Apostolic Delegation - permanent representation of the Holy See to the Catholic Episcopate of the Local Church of a particular state or territory, headed by an apostolic delegate. It differs from the nunciature or inter-nunciature in that it does not perform diplomatic functions. A separate category is represented by representatives of the Holy See in international organizations and at congresses and international congresses. Delegate of the Holy See - represents her in the international organization of which the Holy See is a member. Observer - represents the Holy See in international organizations of which the Holy See is not a member.

Diplomatic representatives of the Holy See in the modern era.

- 1.2.1. The permanent nuncios - represented directly the person of the Pope and not the Holy See, just as the lay ambassadors represented the sovereign, not the state.

- 1.2.2. Apostolic delegates- the first apostolic delegation was established in Aleppo in Lebanon in 1927.

- 1.3. Legaci in the Code of Canon Law of 1917- Book II, title VII, in Chapter V De Legatis Romani Pontificis in canons $265-270$

- 1.3.1. Legaci a latere- canon 266- to represent the Pope as his alter ego

- 1.3.2. Nuncios- canon 267 par.1 - were permanent legates to state governments or to particular churches

- 1.3.3. Interns- canon 267 par.1- on a par with nuncios, but belonged to diplomatic representatives of the second class.

- 1.3.4. Apostolic delegates- canon 267 par. 2 - represented the Holy See only ad intra, i.e. they were established at the particular Churches. They were not of a diplomatic nature.

Diplomatic representatives of the Holy See competent in ecclesiastical relations and relations with states (ad intra and ad extra)

- Nuncio - the rank of ambassador, i.e. a representative of the first class accredited in a given state.

- Pro-nuncio- also belongs to the rank of ambassadors, in practice they are no longer there, they were raised to the rank of nuncio by Pope John Paul II.

- Internuncio - belongs to the representatives of the second class, i.e. to the rank of extraordinary deputies and ministers plenipotentiary.

- The extraordinary legate-

- - legate a latere - special and direct representative of the Pope at church ceremonies or public gatherings

- - a special papal envoy - sent to perform a special pastoral ministry.

Types of representatives of the Holy See in international organizations

- Delegates of the Holy See with right to speak at conferences: AIEA, EC, OSCE, ITU, UPU, WIPO, INTELSAT, CEPT, EUTEL - SAT, UNIDROIT,

- Observers of the Holy See - at international organizations in which the Holy See is not a member.

- - permanent- the UN in NY, the UN in Geneva, UNIDO - Vienna, FAO, IFAD, PAM, CMA in Rome, UNESCO, OAS, OMT, Council of Europe

- -ad hoc- on an ad hoc basis for international congresses and conferences: at ECOSOC, WHO, UNICEF.

- II Republic

- Ambrogio Damiano Achille Ratti (July 3, 1919 -May 25, 1921)- later Pope Pius XI

- Lorenzo Lauri (25 May 1921 - 13 June 1921)- Cardinal

- Filippo Cortesi (13 June 1921 - November 1926 - Archbishop

- Lorenzo Lauri (November 1926 - resigned december 20, 1926) - Cardinal

- Francesco Marmaggi (13 February 1928 - 24 December 1936)- Cardinal 
- Filippo Cortesi (24 December 1936 - 21 August 1939- Archbishop

- Post-war period

- Luigi Poggi (7 February 1975 - 9 April 1986)- Archbishop (Delegate of the Holy See)

- Francesco Collasuono (9 April 1986 - 26 August 1989)- Cardinal

- Józef Kowalczyk (August 26, 1989- June 24, 2010) - Archbishop

- Celestino Migliore (30 June 2010 - 5 August 2016) - Archbishop

- Salvatore Pennacchio (since August 6, 2016) - Archbishop

1. Bogacki Paweł. 2009. The Holy See as an entity of international law. Warsaw. Pax Publishing Institute.

2. Garcia Justo Mullor. 2003. Pontificia Accademia Ecclesiastica, Terzo Centenario 1701-2001. La diplomazia pontificia ieri, oggi e domani. Roma. Pontificia Academia.

3. Geremek Bronislaw. 2004. Opportunity and threat. Politics and diplomacy in his native Europe- D. Maciejewska, Warsaw, Studio Emka, Prymasowskie Gaudentinum publishing house.

4. Kelly John N.D. 1997. Encyclopedia of Popes. Warsaw. State Publishing Institute.

5. Kopiec Jan. 2002. Pszczyna on the route of the Papal Nuncio to Poland in 1705. In the Pszczyńska Land for centuries. Research status, archives, research problems, Andrzej Barciak (ed.), 224-230, Suszec;

6. Kopiec Jan. 2009. Opava a refuge for papal nuncios from 1705 to 1709. In Polska papezska nunciatura. Slezko $v$ cirkevnich dejinach 18. Stoleti, Z. Jirasek (ed), 7-15. Opava.

7. Kowalczyk Józef, 2004, Papal House in Warsaw, Apostolic Nunciature in Poland, Warsaw, Oficyna Publishing and Printing «Adam»,

8. Tygielski Wojciech. 1992. From Rome to the Republic-Studies from the history of the Apostolic Nunciature in Poland XVI-XVII centuries, Warsaw, ed. Foundation «History pro Futuro».

9. Wilk Marian. 2006. John Paul II- Grand Diplomat and Politician. In Vatican Diplomacy, WSSM, Łódź, 2006, «Vatican Diplomacy», p.14-22 and p. 40-44. Agnieszka Królikowska-Dyszlewska, Bogusław Miernik , Higher School of International Studies, Łódź. 